Article

\title{
Mapping Urbanization Dynamics in Major Cities of Colombia, Ecuador, Perú, and Bolivia Using Night-Time Satellite Imagery
}

\author{
Isabel K. Parés-Ramos ${ }^{1, *}$, Nora L. Álvarez-Berríos ${ }^{2}$ and T. Mitchell Aide ${ }^{1}$
}

1 Department of Biology, University of Puerto Rico, P.O. Box 23360, San Juan, PR 00931, USA;

E-Mail: tmaide@yahoo.com

2 Department of Environmental Sciences, University of Puerto Rico, P.O. Box 70377, San Juan, PR 00936, USA; E-Mail: alvarez.nora@gmail.com

* Author to whom correspondence should be addressed; E-Mail: ik.pares@gmail.com; Tel.: +1-787-764-0000 (ext. 4855).

Received: 10 December 2012; in revised form: 8 January 2013 / Accepted: 29 January 2013 / Published: 5 February 2013

\begin{abstract}
By 2050, 90\% of the population in Latin America will live in cities, but there is a lack of up-to-date spatial information about the urban extent and patterns of urbanization in cities of this region. In this study, we analyzed population growth, urban density and urbanization dynamics between 1992 and 2009 in the major cities of Bolivia, Colombia, Ecuador and Perú using Google Earth and DMSP/OLS night-time lights imagery. We used Google Earth to map the urban extent, and time series of night-time lights to analyze spatial patterns of urban development. The dominant urban development patterns were: high-density compact in Bogotá, Cali, Guayaquil, and Medellín; high-density expansive growth in La Paz/El Alto; low-density expansive in Quito and Santa Cruz; and a mix of high-density compact and suburban growth in Lima. Urban growth occurred largely along the periphery of cities, influenced by the local landscape and by demographic and socioeconomic factors such as immigration and housing prices. Urban density in Colombia $\left(>20,000\right.$ per $/ \mathrm{km}^{2}$ ) was among the highest in the world. Future growth in the region will probably be characterized by densification and slow urban expansion. This study also validates the utility of Google Earth and night-time lights for monitoring urbanization.
\end{abstract}

Keywords: DMSP/OLS night-time lights; Google Earth; population change; urban development; urban density; Bolivia; Colombia; Ecuador; Perú 


\section{Introduction}

Cities occupy a relatively small fraction of the Earth's land area, but serve as habitats for more than half of the human race. In 2011, the global population reached $\sim 7$ billion, and more than 3.5 billion lived in urban areas [1]. The global urban population is expected to reach $\sim 6.3$ billion by 2050 , meaning that $\sim 70 \%$ of the global population will live in cities by the middle of this century [2]. Over the last 150 years, urbanization, or the concentration of people in cities, has been the phenomenon that has most radically transformed society. Britain became the first urban society in the early 1900s, when only $\sim 5.5 \%$ of the global population lived in cities of more than 100,000 inhabitants [3]. Today, more people live in cities because they are the main providers of employment, housing, education, and health care, and they are also major centers of culture, innovation, and economic activity [4]. Cities have undoubtedly become the engine of the global economy, generating between $80 \%$ and $95 \%$ of the global GDP [5,6].

Despite these positive aspects of cities, their rapid growth has intensified the demand and competition for resources (e.g., land, water, energy, agricultural products), often at high environmental and social costs [7]. Climate change, loss of prime agricultural land, air and water pollution, overcrowding, crime, traffic congestion, poverty, and social exclusion are often associated with urbanization [8,9]. For instance, $\sim 75 \%$ of the global energy consumption and $\sim 80 \%$ of the greenhouse gas emissions occur in cities [10]. Furthermore, wealth in cities is unequally distributed, and $\sim 30 \%$ of the total urban population ( $\sim 1$ billion) lives in slums or poor informal settlements lacking basic services [11]. Informal settlements are often the result of rapid and uncontrolled urbanization due to immigration, the incapacity of public and private institutions to provide low-income housing, and inappropriate land administration and planning [12,13]. Informal settlements will continue to grow to accommodate population growth because they constitute an important source of urban housing in low and middle-income countries [14].

The challenges of urbanization are becoming more complex since recent population growth and urban expansion has concentrated in low (<US \$1,000 GNI per capita) and middle (<US \$12,500 GNI per capita) income countries [4,15]. Between 1995 and 2005, 160,000 people moved into cities each day in Africa, Asia and Latin America [9]. Moreover, by 2050, 95\% of urban expansion is expected to take place in low and middle-income countries [11]. Thus, more attention should be given to the study of urbanization dynamics in these regions, particularly in Latin America where $90 \%$ of the population will live in cities by 2050 [16]. Despite being the most urbanized region in the developing world [2], there is a lack of up-to-date spatial information on the urban extent of cities and patterns of urbanization in Latin America [17,18]. Developing accurate maps and spatial information of urban areas will help us better understand how population growth is influencing the patterns of urbanization. Spatial information is crucial to understand how population dynamics are shaping the structure and characteristics of cities, including population density, urban land uses, and land consumption.

The main goal of this study was to collect spatial information and describe urbanization dynamics between 1992 and 2009 in the major cities of Bolivia (Santa Cruz and La Paz/El Alto), Colombia (Bogotá, Cali, and Medellín), Ecuador (Guayaquil and Quito) and Perú (Lima) using remote sensing and geographic information systems (GIS). Specifically, we used night-time lights imagery derived from the Defense Meteorological Satellite Programs Operation Linescan System (DMSP-OLS) as a 
spatial indicator of urban development, and Google Earth images as a source of land-cover data. For each city, we: (1) mapped the extent of the urban area using Google Earth, (2) estimated the urban population density for 2007/2009, (3) calculated the annual urban population growth rate between 1992 and 2009, and (4) identified the major trends in urban development based on changes in the intensity and distribution of night-time lights between 1992 and 2009. We also compared the level and rate of urbanization among cities, discussed possible factors shaping urban development in this region, and validated the utility of Google Earth and night-time lights for monitoring urbanization dynamics.

\section{Study Area}

\subsection{Andean Region-Bolivia, Colombia, Ecuador, and Perú}

In 2009, the total population in the region was $\sim 98$ million, and $\sim 74 \%$ lived in urban areas [19]. Colombia is the most populated country with $~ 44.4$ million inhabitants, followed by Perú with 29.1 million, Ecuador with $\sim 14.3$ million, and Bolivia with $\sim 10.3$ million [19]. Perú is the most urbanized with $\sim 77 \%$ of the population living in cities, followed by Colombia $(\sim 75 \%)$, Bolivia ( $69 \%$ ), and Ecuador ( 65\%). Between 1992 and 2009, $\sim 88 \%$ of the total population growth in this region occurred in urban areas (from 47.4 million to 71.9 million) [20]. In 2010, Colombia had the highest GDP per capita with $\$ 6,225$, followed by Perú $(\$ 5,400)$, Ecuador $(\$ 4,000)$ and Bolivia $(\$ 1,980)$ [15]. For the analyses, we selected the eight largest and most populated cities in the region in 1992 (Figure 1).

\subsection{City Profiles}

\subsubsection{Bogotá, Cali, and Medellín (Colombia)}

Bogotá, the capital of Colombia, is located on a high plateau at 2,600 m in the Sabana de Bogotá, an old sedimentary basin in the center of the country [21]. The city is limited by the Andes to the east and by the Bogotá River to the west (Figure 1). Cali (Santiago de Cali) is the capital of the Cauca Department, one of the most important agricultural regions [22]. The city is located in a vast tract of alluvial soil at $\sim 1,000 \mathrm{~m}$ and is limited to the west by the Andes, and bordered on the east by the Río Cauca (Figure 1). Medellín is the capital of the Antioquia Department and is the principal manufacturing and industrial area (e.g., textile production) in Colombia [23]. The city is located within the Aburra Valley at an altitude of $\sim 1,500 \mathrm{~m}$.

\subsubsection{Quito and Guayaquil (Ecuador)}

Quito, the capital of Ecuador, is located in the Guayllabamba river basin in the country's northern highlands. The city is located at an altitude of $\sim 2,850 \mathrm{~m}$ on the eastern slopes of the Guagua Pichincha volcano [24] (Figure 1). Guayaquil is the capital of the Guayas Province, along the southwestern coast of Ecuador. The city is located in a delta, bordered to the east by the Guayas River and to the south by the Estero River, mangrove forests, and shrimp farms [25] (Figure 1). It is the country's principal port and main center for business and manufacturing industries. 
Figure 1. Map of the Andean region in South America and location of the eight cities studied. Includes the city polygons (i.e., urban area), delimited using images from Google Earth between 2007 and 2009.

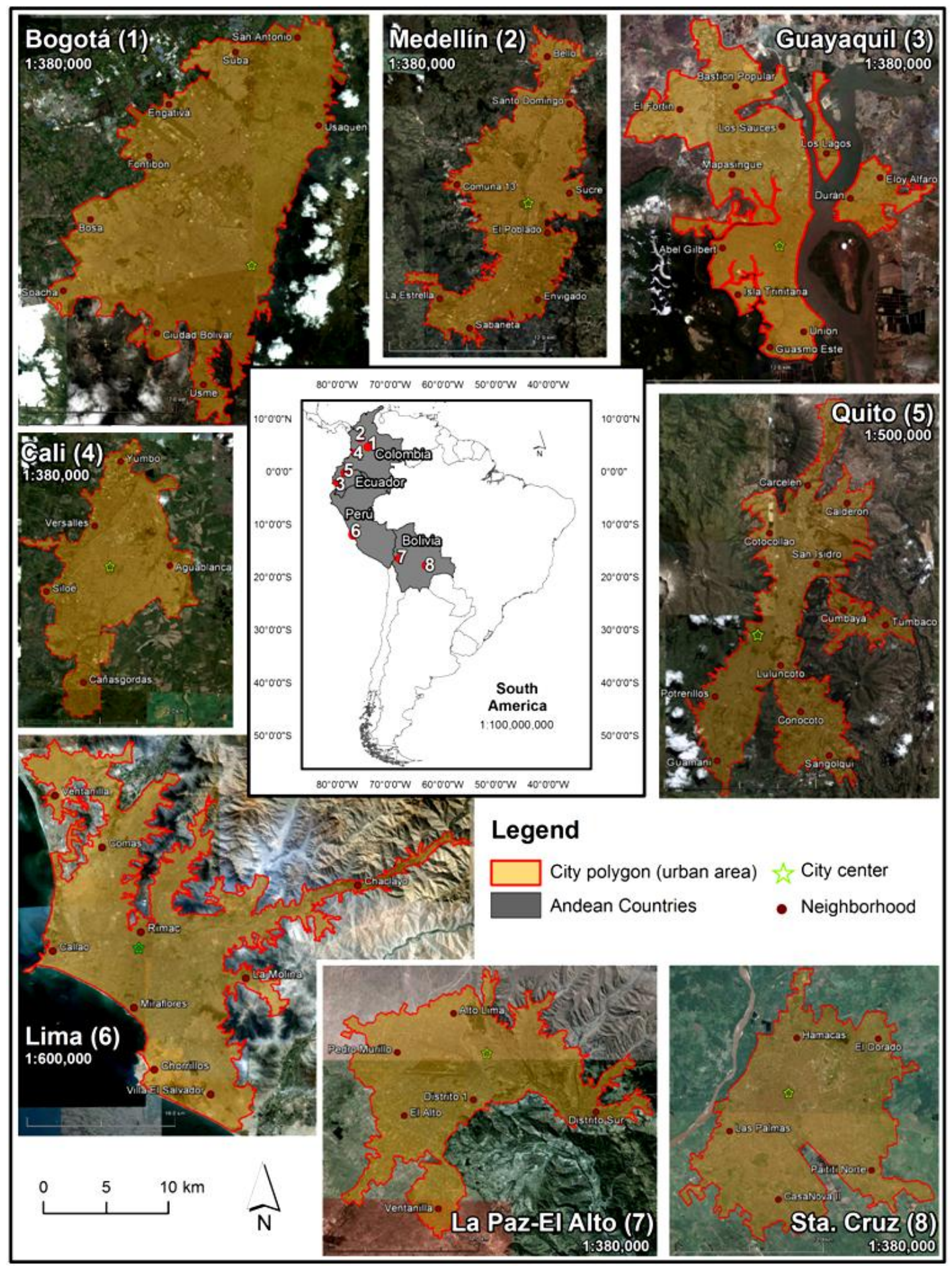

\subsubsection{Lima (Perú)}

Lima is the capital and largest city of Perú, about ten times larger than Arequipa, the country's second city [26]. Lima is located in a coastal desert along the Pacific coast, on the banks of the 
Chillón, Rímac, and Lurín rivers at an altitude of 160 m (Figure 1). It is the fifth largest city in Latin America, and one of the main financial centers [26].

\subsubsection{La Paz/El Alto and Santa Cruz de la Sierra (Bolivia)}

The conurbation of La Paz/El Alto is the world's highest city at an altitude of $\sim 3,600 \mathrm{~m}$. La Paz, the administrative capital of Bolivia (i.e., seat of government), is located in a steep, enclosed basin of the eastern Bolivian Andes, along La Paz River [27]. El Alto is a satellite city located on flat terrain above La Paz at an altitude of $\sim 4,150 \mathrm{~m}$ on the Altiplano, a high plateau to the west of La Paz [27] (Figure 1). Santa Cruz de la Sierra is the capital of the department of Santa Cruz, and it is located in the central lowlands of Bolivia at an altitude of $\sim 416 \mathrm{~m}$. It is bordered by the Piraí River to the west, and by agricultural plains to the north, east, and south (Figure 1). Santa Cruz is a major service hub for the oil and natural gas industry and the agricultural sector [28].

\section{Data and Methods}

\subsection{Demographic Data}

Urban population data at the municipality level was obtained from national censuses of various years: Bolivia in 1992 and 2010 [29], Colombia in 1993 and 2010 [30], Ecuador in 1990 and 2010 [31], and Perú in 1993 and 2005 [32]. For each city, we estimated the urban population in 1992 and 2009, and calculated the annual population growth rate during the 17-year study period. We extrapolated the population data to 1992 and 2009 to match the dates of the night-time light images used for the analysis of urbanization dynamics using the following equations:

$$
\begin{gathered}
\mathrm{PE}_{(\mathrm{y})}=\mathrm{e}^{\mathrm{rt}} \times \mathrm{P} 1 \\
\mathrm{r}=\operatorname{In}[(\mathrm{P} 2 / \mathrm{P} 1)] /(\mathrm{t} 2-\mathrm{t} 1)
\end{gathered}
$$

The extrapolations were calculated using the average annual geometric growth rate $(r)$, the difference in years between the actual and the predicted year $(t)$, and the population count for the first reference year $(P 1)$. For the annual geometric growth rate $(\mathrm{r}), \ln$ is the natural $\log , P 1$ and $P 2$ are the population counts for the first and second reference years, and $t 1$ and $t 2$ are the first and second reference years. The annual population growth rate (APGR) was calculated using the following equation:

$$
\mathrm{APGR}=100 \times\left(\left(\mathrm{PE}_{\mathrm{end}} / \mathrm{PE}_{\text {start }}\right)^{(1 / \mathrm{d})}-1\right)
$$

where $P E_{\text {start }}$ is the population in $1992, P E_{\text {end }}$ the population in 2009 , and $d$ the time span in years.

\subsection{Using Google Earth for Urban Mapping and for Collecting Land Cover Data}

Google Earth is increasingly being used as an alternative remote sensing platform for studying and mapping land use dynamics worldwide [33]. The high resolution imagery (sub-meter to 4-m) from commercial satellites (e.g., Quickbird, IKONOS) available in Google Earth serve as land cover validation data [34]. Researchers are using these images for calibrating land cover data derived from Landsat or MODIS satellite data to improve image classification accuracy [33,35]. For this study, we used Quickbird high resolution imagery available in Google Earth (v. 6.1.0) to map the urban area of 
Bogotá, Cali, Medellín, Guayaquil, La Paz/El Alto, Lima, Quito, and Santa Cruz (Figure 1). We used the most recent Quickbird images that covered the entire urban area to build one polygon per city that delimited the urban extent (Figure 1).

In this study, the measure of urban land area, or urban extent, refers to the area of continuous urban development, defined as the inner city plus continuous built-up environs regardless of administrative boundaries. Therefore, the city polygons included a mix of urban land uses (e.g., residential, commercial, industrial, and recreational) and different types and intensities of urban development (e.g., urban core, suburban, scattered) within the city's landscape. To ensure a consistent data collection process we established a set of mapping guidelines to determine the boundary of the urban area. The city polygons include the main built-up area of the city plus any contiguous urban land use. Any urban land use, which occurred less than $1 \mathrm{~km}$ from the continuous built-up area was also included in the polygon (Figure 1). The total area of the polygon is reported as the urban area of each city, which was used to calculate the average urban population density in 2007/2009. Finally, the polygons in $\mathrm{kml}$ format (i.e., Google Earth format) were uploaded into ArcGIS [28] and used as the base maps for the spatial analyses of night-time lights (NTL). Our measure of urban area is equivalent to the term "urban agglomeration" used by the United Nations to define and measure urban areas worldwide [19]. Accordingly, we used the UN urban population density estimates [19] to compare our estimates of urban densities with urban densities in other Latin American cities and major cities around the world.

\subsection{DMSP/OLS Night-Time Satellite Data}

Night-time lights (NTL) imagery derived from the Defense Meteorological Satellite Programs Operation Linescan System (DMSP-OLS) is available from the National Oceanic and Atmospheric Administration (NOAA) (http://www.ngdc.noaa.gov/dmsp/download.html). Each image is a composition of cloud-free scenes from the DMSP-OLS satellite that orbits the earth at an altitude of $830 \mathrm{~km}$, providing global coverage twice per day [36]. For this study, we used stable night-time lights time images (1992-2009), which only contain permanent light sources from cities, towns, and other continuous sources of light (e.g., gas flares or mining and oil exploration sites). These images have a resolution of approximately $1 \mathrm{~km} \times 1 \mathrm{~km}$, and each pixel's value (Digital Number (DN)) represents light intensity, ranging from DN 0 (no lights) to DN 63 (brightest lights). Since the 1980s, night-time lights data have been effectively used to detect human presence and activities at global and regional scales [37-41]. These data have served to monitor and estimate energy consumption [36,37,42,43], economic activity [42,44-46], population density [39,47,48], and most recently to develop a human development index [49]. Time series of NTL have also been successfully applied to analyze the trends of urban expansion and urban dynamics at different spatial scales (e.g., national, regional, and global) [41,50-52]. The countries in the present study have high urban electrification rates since the 1990s, justifying the use of NTL data to monitor urbanization dynamics in this region. By 1990, all countries had over $90 \%$ urban electrification rates and by 2009 the percentage increased to $99 \%$ [53]. 
NTL Image Classification and Threshold Analysis

The first step of the analysis of night-time lights was to establish a correlation between the DN values of the NTL images and different intensities of urban development (Figure 2). The NTL image classification and thresholding analysis used is described in detail in Alvarez-Berríos et al. [20], and is summarized below. We first defined four types of urban land-use classes using indices of urban compactness following Galster et al. [54]: no-development, scattered development, suburban development, and compact development. We then used Google Earth's Quick Bird and IKONOS images (circa 2000-2009), to find and delineate 76 sample polygons representing the four urban land-use types across the four countries and in different years. We imported the sample polygons $(\mathrm{kml}$ format) into a shapefile format using GIS, and superimposed each polygon with the corresponding NTL image to record the minimum and maximum DN values of NTL within each polygon.

We used a multivariate analysis of variance to examine the range of DN values associated with each land-use class, and found that there were significant differences in the minimum and maximum DN values of NTL for each of the four land-use classes (ANOVA: minimum $f=138.30, p<0.001$; maximum $f=135.58, p<0.001)$. The range of $\mathrm{DN}$ values for each class was: (1) DN $0-5$, no-development; (2) DN > 5-20, scattered; (3) DN > 20-52, suburban; (4) DN > 52-63, compact (Figure 2). We further subdivided the last class into compact development (DN > 52-60) and central core (DN > 60-63), to distinguish the city center (i.e., most dense urban area) from other urban land classes (Figure 2). These two categories were statistically different (Mann-Whitney $U$-test: minimum $u=8, p=0.02$; maximum $u=1.5, p=0.003$ ). The central core class was established after analyzing the distribution of DN values within the city polygons, which showed that all the city centers had DN values over 60. These ranges were used to classify the NTL images for 1992 and 2009 into five light "intensity" classes, as a proxy of each land-use type (Figure 2). Finally, we mapped the distribution of the NTL classes in 1992 and in 2009 within the city polygons, and quantified the changes in area of each NTL class from 1992 to 2009 to determine the dominant patterns of urban development per city.

Figure 2. Google Earth images showing samples of the different land-use classes and their corresponding night-time lights Digital Value (DN) ranges. Sites: Lima, Perú and Santa Cruz, Bolivia.

DN 0

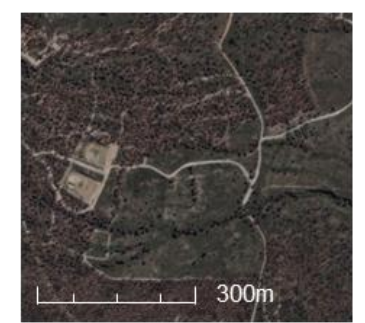

no-development

(DN 0-5)

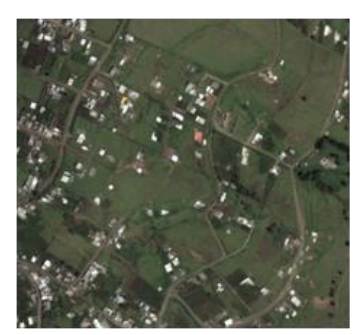

scattered

(DN >5-20)

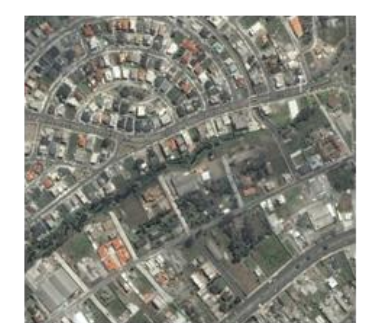

suburban

(DN >20-52)

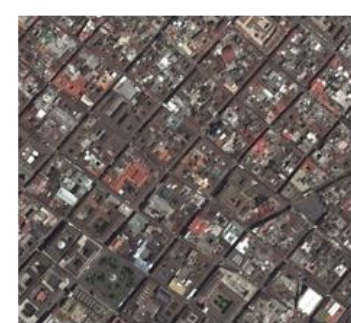

compact

(DN >52-60)

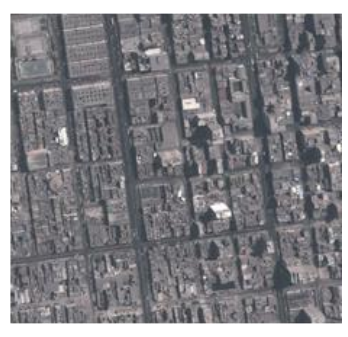

central core

(DN >60-63) 


\section{Results}

\subsection{Population Dynamics from 1992 to 2009 and Urban Extent of the Major Cities in the Andean Region}

The eight cities varied in population size and growth (Table 1). In 1992, the total population of the eight cities was approximately 20 million people. Lima ( $\sim 6$ million) and Bogotá ( $\sim 5$ million) were the most populated, while Santa Cruz $(\sim 710,000)$ was the least populated (Table 1). By 2009, the population increased to over 30 million people. The populations of Bogotá and Lima grew by 2.5 and 2.3 million respectively, but at relatively low rates compared to the rest of the cities (Table 1). Santa Cruz doubled its population, becoming the fastest growing city in the region with an annual growth rate of $4.8 \%$, twice the rate of all the other cities (Table 1). Overall, population growth rates were higher in cities with smaller populations in 1992, such as Guayaquil (2.8\%), Quito (2.7\%) and La Paz/El Alto (2.6\%). Although all cities experienced population growth, they varied greatly in terms of urban extent, population density, and administrative divisions. In 2007-2009, the extent of the urban built up area ranged from $\sim 132 \mathrm{~km}^{2}$ in Cali to $\sim 760 \mathrm{~km}^{2}$ in Lima (Table 1). The population densities of the two largest cites, Lima $\left(>11,100\right.$ people $\left./ \mathrm{km}^{2}\right)$ and Bogotá $\left(>20,900\right.$ people $\left./ \mathrm{km}^{2}\right)$, varied considerably. Bogotá was twice as dense as Lima because it had a similar population size, but its built-up area $\left(\sim 364 \mathrm{~km}^{2}\right)$ was approximately half of Lima $\left(\sim 760 \mathrm{~km}^{2}\right)$. Medellín was the most densely populated $\left(>21,000\right.$ people $\left./ \mathrm{km}^{2}\right)$, followed by Bogotá and Cali (Table 1). Guayaquil also had a relatively high population density $\left(>13,000\right.$ people $\left./ \mathrm{km}^{2}\right)$, and Quito had the lowest $(>6,500$ people $/ \mathrm{km}^{2}$ ). La Paz/El Alto ( $>9,000$ people $\left./ \mathrm{km}^{2}\right)$ and Santa Cruz $\left(>7,000\right.$ people $\left./ \mathrm{km}^{2}\right)$ in Bolivia also had low population densities. The number of administrative divisions included in the city polygons also varied; Lima had 38 municipalities, while Santa Cruz had only one (Table 1).

Table 1. Population change from 1992 to 2009, density and urban extent of the eight major cities in the Andean region.

\begin{tabular}{|c|c|c|c|c|c|c|c|c|}
\hline Country & City & $\begin{array}{c}\text { Urban } \\
\text { Population } \\
\text { in } 1992\end{array}$ & $\begin{array}{c}\text { Urban } \\
\text { Population } \\
\text { in } 2009\end{array}$ & $\begin{array}{c}\text { Annual } \\
\text { Population } \\
\text { Growth Rate } \\
\text { 1992-2009 } \\
\end{array}$ & $\begin{array}{c}\text { Google } \\
\text { Earth } \\
\text { Image } \\
\text { Year } \\
\end{array}$ & $\begin{array}{c}\text { Urban } \\
\text { Area } \\
\text { (extent) }\end{array}$ & $\begin{array}{c}\text { Urban } \\
\text { Population } \\
\text { Density } \\
\left(\text { per } / \mathbf{k m}^{2}\right) \\
\end{array}$ & $\begin{array}{c}\text { Number } \\
\text { of } \\
\text { Munici- } \\
\text { palities }\end{array}$ \\
\hline \multirow[t]{2}{*}{ Bolivia } & La Paz/El Alto & $1,189,000$ & $1,847,000$ & 2.6 & 2009 & $200 \mathrm{~km}^{2}$ & 9,235 & 4 \\
\hline & Santa Cruz & 710,000 & $1,584,000$ & 4.8 & 2009 & $221 \mathrm{~km}^{2}$ & 7,167 & 1 \\
\hline \multirow[t]{3}{*}{ Colombia } & Bogotá & $5,030,000$ & $7,609,000$ & 2.5 & 2009 & $364 \mathrm{~km}^{2}$ & 20,904 & 2 \\
\hline & Cali & $1,976,000$ & $2,664,000$ & 1.8 & 2007 & $132 \mathrm{~km}^{2}$ & 20,182 & 2 \\
\hline & Medellín & $2,199,000$ & $3,231,000$ & 2.3 & 2008 & $151 \mathrm{~km}^{2}$ & 21,397 & 6 \\
\hline \multirow[t]{2}{*}{ Ecuador } & Guayaquil & $1,711,000$ & $2,732,000$ & 2.8 & 2009 & $209 \mathrm{~km}^{2}$ & 13,072 & 3 \\
\hline & Quito & $1,372,000$ & $2,165,000$ & 2.7 & 2008 & $331 \mathrm{~km}^{2}$ & 6,541 & 14 \\
\hline Perú & Lima & $6,106,000$ & $8,462,000$ & 1.9 & 2009 & $760 \mathrm{~km}^{2}$ & 11,134 & 38 \\
\hline TOTAL & & $20,292,000$ & $30,294,000$ & 2.4 & & & & 70 \\
\hline
\end{tabular}




\subsection{Urbanization Dynamics Based on Night-Time Lights Data}

\subsubsection{Level and Rate of Urbanization between 1992 and 2009}

The time series analysis of the average light intensity or DN value per city between 1992 and 2009 revealed differences in the level of urbanization and in the rate of urban growth between cities (Figure 3). We identified three different trajectories of urban growth: (1) cities with very high levels of urbanization and little or no change in mean light intensity (Bogotá, Medellín, and Cali); (2) cities with relatively high levels of urbanization in 1992 that experienced slow urban growth (Lima and Guayaquil); and (3) cities with low levels of urbanization in 1992 that experienced rapid urban growth (La Paz/El Alto, Quito, and Santa Cruz). The analyses also showed that Quito, Santa Cruz, and particularly La Paz/El Alto grew rapidly between 1992 and 2000 (Figure 3). Overall, we identified a deceleration in the rate of urban growth between 2000 and 2009 in all cities (Figure 3).

Figure 3. Time series analysis of the average light intensity or DN value per city between 1992 and 2009.

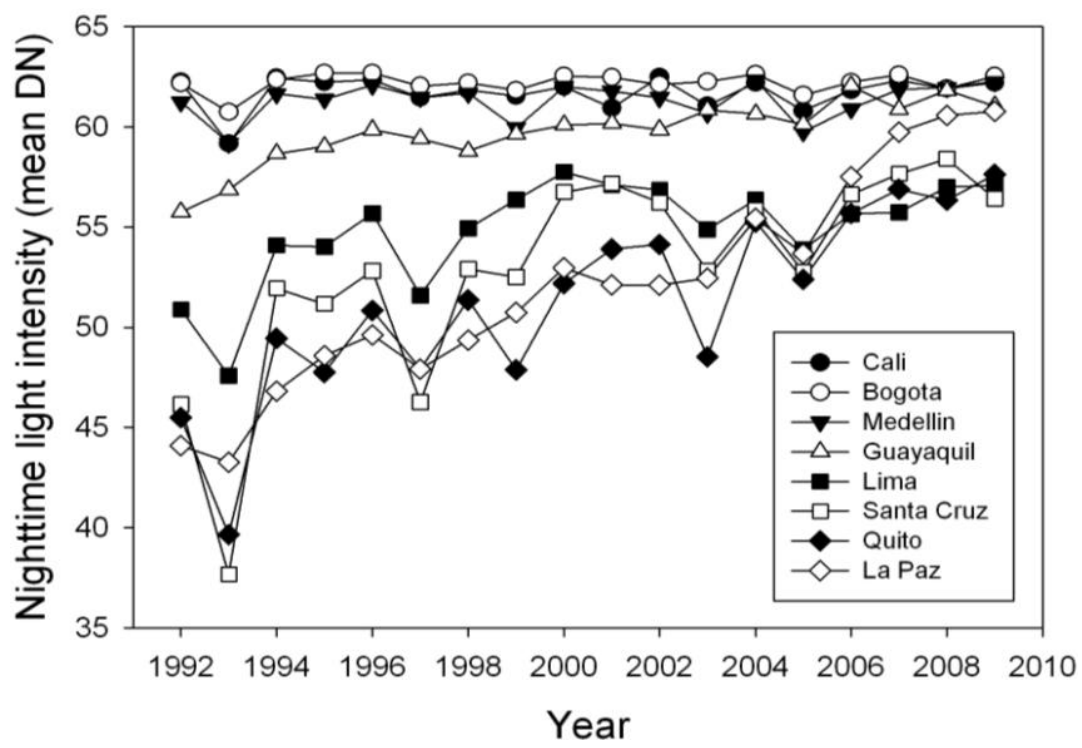

The distribution of light classes within the city polygons, showed that in 1992, most of the built-up areas in Bogotá (83\%), Cali (68\%), Medellín (68\%), and Guayaquil (62\%) were classified as central core (DN > 60-63), indicating high levels of urbanization (Figures 4 and 5(a)). In contrast, the central core area of Quito (10\%) and Santa Cruz (16\%) were much smaller, and the majority of the built-up area was classified as suburban (DN > 20-52) (Figures 4 and 5(a)). In both Lima and La Paz/El Alto, the central core covered $\sim 35 \%$ of the built-up area in 1992; however, in Lima, the suburban class also covered a large area (33\%), while in La Paz/El Alto $\sim 23 \%$ of the city polygon was classified as undeveloped (DN 0-5) or scattered development (DN > 5-20) (Figures 4 and 5(a)).

\subsubsection{Changes in Area and in the Distribution of Urban Land-Use Classes}

The major change in the Colombian cities of Bogotá, Medellín, and Cali was the conversion of the suburban and compact classes to the central core class (i.e., densification) (Figures 4 and 5(a,b)). By 
2009 , over $90 \%$ of the built-up area in these cities was classified as central core, a clear example of the densification process (Figures 4 and 5(b)). This densification occurred mainly along the southern and eastern peripheries of these cities (Figure 4(b)). The urban dynamics of Guayaquil, Ecuador were similar to those of the Colombian cities, characterized by a transition from the suburban and compact classes to the central core class (Figures 4 and 5(a,b)). The central core expanded from $117 \mathrm{~km}^{2}$ to $148 \mathrm{~km}^{2}$, covering 78\% of the built-up area in 2009 (Figures 4 and 5(b)). The central core extended to the northwest of the city center, but mostly to the east across the Guayas River into areas classified as suburban in 1992 (Figure 5(b)). Urban growth in Quito, Ecuador was much more dynamic (Figures 4 and 5(a,b)). The central core area of Quito increased from $\sim 32 \mathrm{~km}^{2}$ to $\sim 150 \mathrm{~km}^{2}$ (Figure 5(b)), extending north, east and south of the city center into areas classified as low (DN > 5-20) and medium intensity (DN > 20-52) in 1992 (Figures 4 and 5(b)). Although the city experienced a dramatic increase in the central core class, more than $40 \%$ of the city remains classified as compact $\left(\sim 134 \mathrm{~km}^{2}\right)$, and $14 \%$ as suburban $\left(\sim 7 \mathrm{~km}^{2}\right)$ (Figures 4 and $5(\mathrm{~b})$ ).

Figure 4. Change in the distribution of the night-time lights (NTL) classes between 1992 and 2009 within the city polygons.
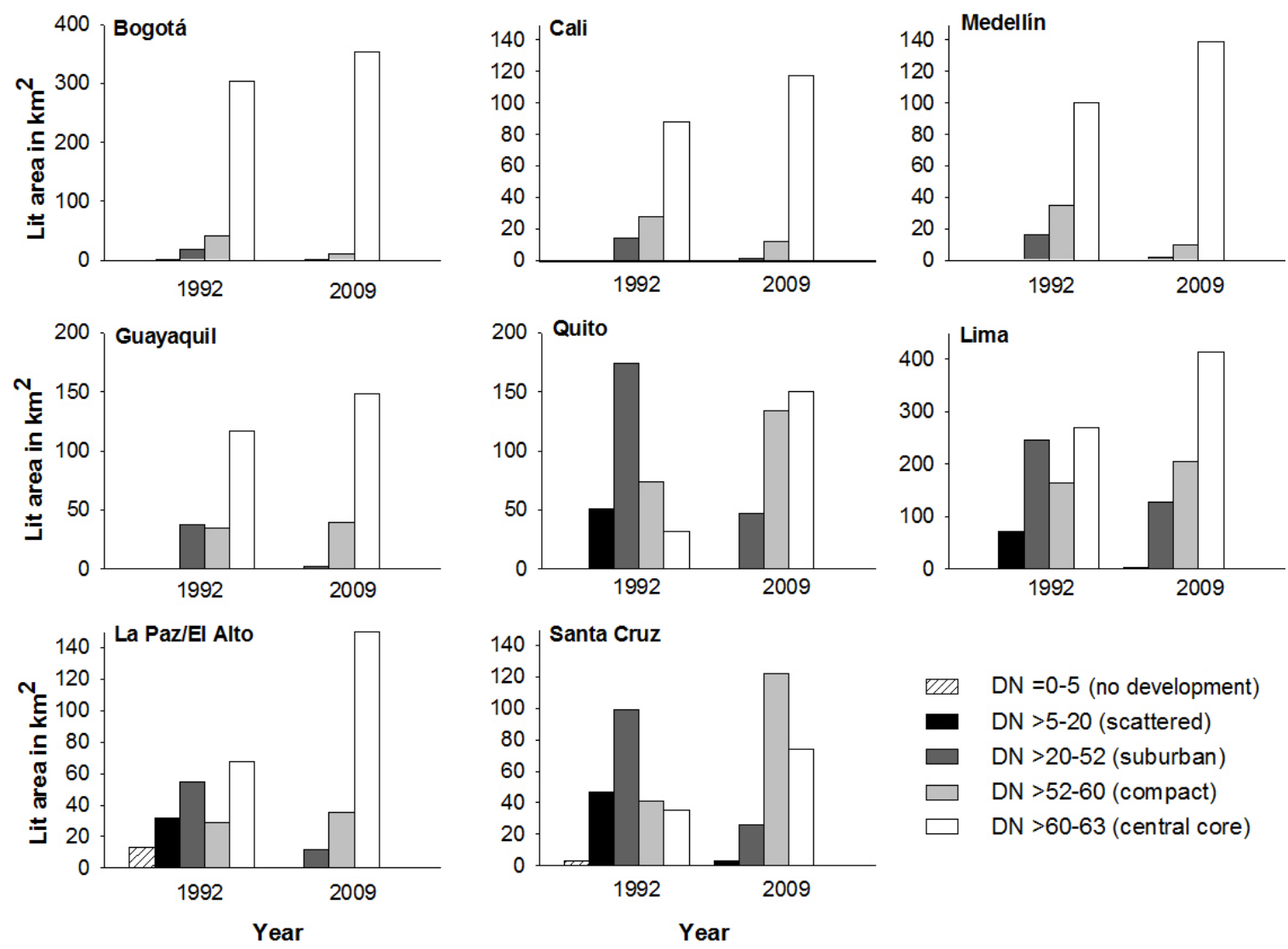

In Bolivia, both cities experienced important urban changes, particularly La Paz/El Alto where the central core more than doubled, from $68 \mathrm{~km}^{2}(35 \%)$ to $150 \mathrm{~km}^{2}(76 \%)$, extending into areas classified as scattered and undeveloped to the west of the city center in El Alto municipality (Figures 4 and 5(b)). Santa Cruz is unique because it was the only city where the area of the compact class $\left(\sim 122 \mathrm{~km}^{2}\right)$ was larger than the central core area $\left(\sim 74 \mathrm{~km}^{2}\right)$ in 2009 (Figures 4 and 5(b)). Although the central core more 
than doubled, extending south and east (Figure 5(b)), it only covered 33\% of the total built-up area, with the majority classified as compact (55\%) and the rest as suburban (12\%) (Figures 4 and 5(b)).

Figure 5. (a) Map of the distribution of the night-time lights (NTL) classes in 1992 within the city polygons. (b) Map of the distribution of the night-time lights (NTL) classes in 2009 within the city polygons.
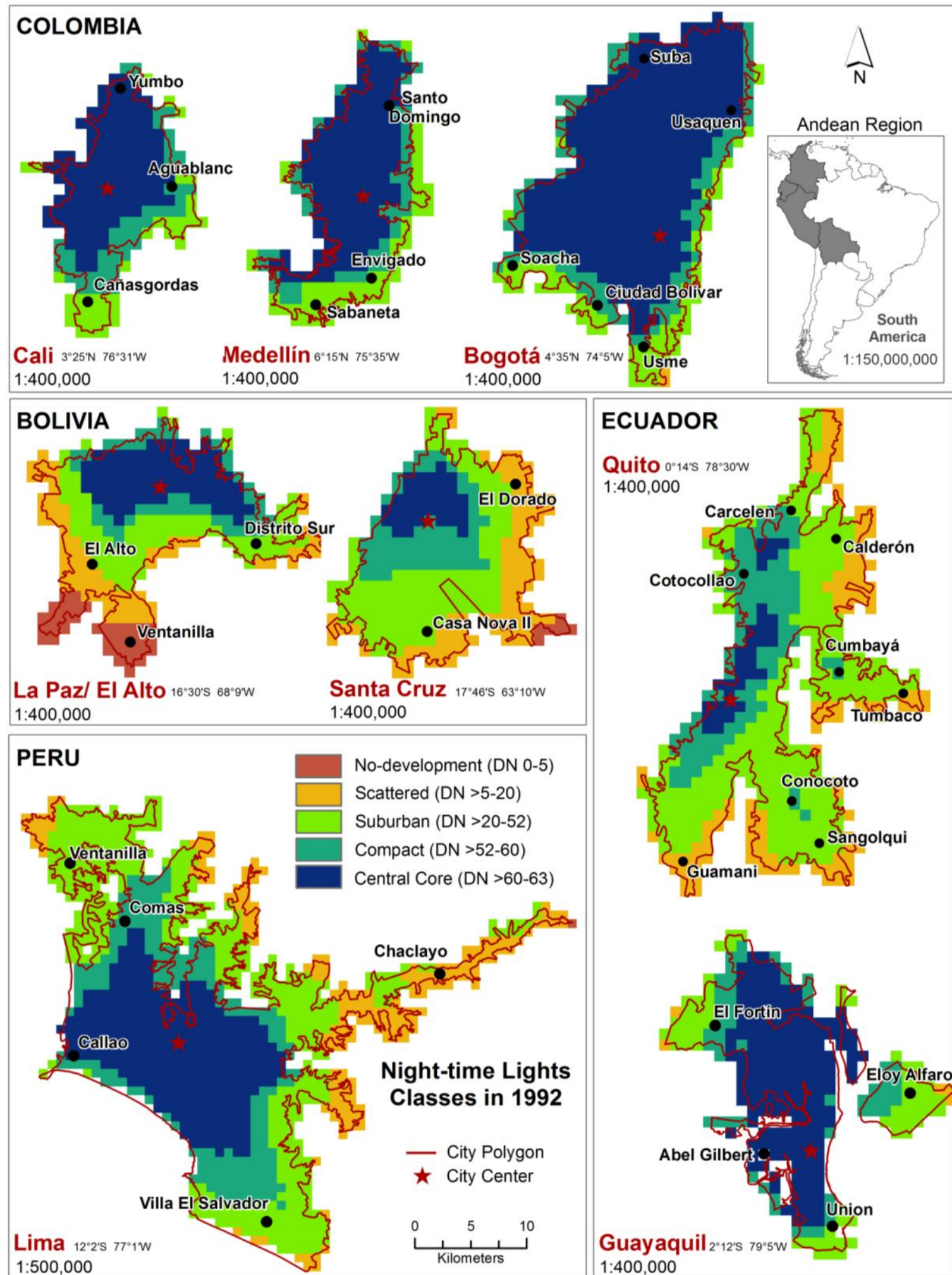

No-development (DN 0-5)

Scattered $(\mathrm{DN}>5-20)$

Suburban $(\mathrm{DN}>20-52)$

Compact ( $\mathrm{DN}>52-60)$

Central Core (DN >60-63)

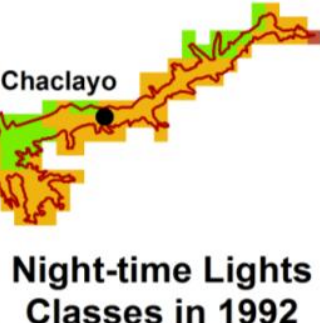

- City Polygon

$\star$ City Center

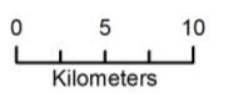

Guayaquil $_{2^{\circ} 12^{\prime} \mathrm{S}} 79^{\circ} 5 \mathrm{~W}$ 1:400,000

(a) 
Figure 5. Cont.

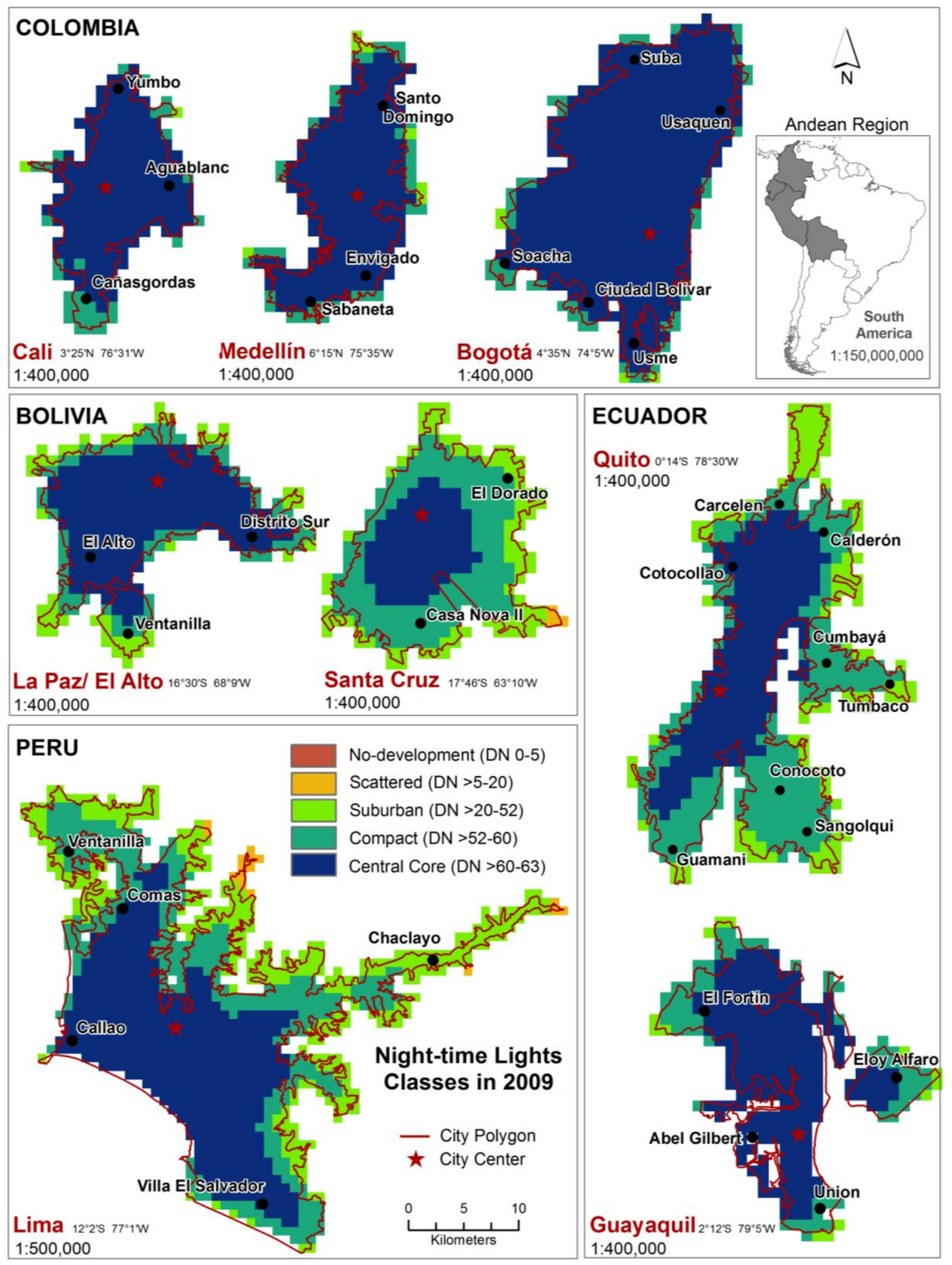

(b)

In Lima, Perú, the central core class increased from $269 \mathrm{~km}^{2}$ (36\%) to $414 \mathrm{~km}^{2}$ (55\%), expanding mostly to the south and along the northern and western edges of the city (Figures 4 and 5(b)). In 1992, $71 \mathrm{~km}^{2}$ were classified as scattered development, by 2009 virtually all of these areas were converted into urban class with high light intensities (Figure 5(b)). 


\subsubsection{Dominant Patterns of Urban Development}

The urbanization dynamics of the eight cities varied greatly (Figures 3-5). The dominant pattern of urban growth in Bogotá, Cali, Medellín, and Guayaquil was high-density compact development. The populations of these cities grew considerably between 1992 and 2009 (Bogotá 2.5 million, Medellín $\sim 1$ million, Guayaquil $\sim 1$ million and Cali $\sim 680,000$ ), but the urban area did not expand much, resulting in cities with very high densities (Table 1). In contrast, the dominant pattern of urban growth in Quito and Santa Cruz was low-density expansive development. These cities were the fastest growing cities, but they had the lowest population densities and the smallest central cores areas in 2009 (Table 1, Figure 4). For example, the central core of Quito increased 5-fold, but only covered $\sim 4 \%$ of the total built-up area in 2009. Similarly, Santa Cruz, which had the highest annual population growth rate, doubled its population, but the central core area only covered $\sim 33 \%$ of the total built-up area in 2009 (Figures 4 and 5(a,b)). The population of Lima increased by $\sim 2.3$ million people, but the patterns of urban development varied greatly throughout the city. The central core of Lima expanded to the south and north, while development to the east was dominated by suburban and compact development (Figure 5(b)). The most dynamic and rapidly changing city was La Paz/El Alto, which experienced the most expansive urban growth, but at relatively high densities since virtually all new development was classified as central core ( $76 \%$ of the total built-up area in 2009) (Table 1 and Figure 5(b)). Much of the new central core was located in the municipality of El Alto, in areas that were classified as rural or scattered in 1992 (Figures 4 and 5(a)).

\section{Discussion}

\subsection{Utility of Google Earth and Night-Time Lights Data for Monitoring Urbanization Dynamics}

The high resolution imagery available in Google Earth and the DMSP-OLS stable night-time lights products were useful and reliable sources of urban geospatial data. Google Earth imagery is a practical and accessible tool for mapping urban areas because it facilitates the identification of urban landscape characteristics, such as the type (e.g., informal settlements) and intensity of development (e.g., low rise $v s$. high rise). Google Earth can also be used to collect validation and reference data for accuracy assessments [33]. DMSP-OLS night-time lights (NTL) data are also very useful because they provide annual worldwide coverage for urban studies and are freely available online. Moreover, the high contrast between lit and unlit pixels in NTL data enhances the identification of urban areas, and helps to overcome misclassification of urban land cover caused by their spectral similarities with barren terrains and deserts when using other satellite imagery [7,55]. However, a limitation of this dataset is that NTL images have a tendency to overestimate the extent of the urban area because of the "overglow" effect [31]. This problem can be reduced by only including areas with DN values that are above a given threshold [32]. These thresholds should be defined based on the objectives of the study, and by using reference samples from other land cover sources (e.g., Google Earth) [32,33].

Another limitation of NTL is oversaturation [32,33], which affects the detection of changes in highly urbanized areas. This is because NTL saturate at a maximum DN value of 63 and any increase in brightness is not detected [6,34]. Despite efforts to correct this problem [34], oversaturation continues to be an issue for NTL analysis [6], and may have hindered the detection of changes in 
highly urbanized cities in our study. This suggest that NTL data are better at capturing urbanization dynamics in cities with a recent history of urban growth (e.g., La Paz/El Alto), rather than small changes in older more stable cities (e.g., Bogotá).

\subsection{Factors Shaping Urban Development in the Andean Region}

NTL data were very useful for determining the direction of urban growth and providing a standard measure to analyze and compare spatial patterns of urban development among cities in the Andean region (Figures 4 and 5(a,b)). In the following sections, we discuss possible factors influencing the urbanization dynamics, including demographic and socioeconomic factors, the geography of the region, and housing prices.

\subsubsection{Andean Geography}

Geography and local landscape characteristics played a major role in shaping urbanization dynamics. In Colombia, the high-density compact urban development pattern detected by NTL could be associated with the steep geography of the Andes. The cities of Bogotá, Cali, and Medellín were built in the foothills of the Andes, restricting land availability for further urban expansion and causing the densification of existing urban areas. Often, the edges of cities in this region are marked by steep slopes and terrains inadequate for building, but the pressures of population growth, due to natural increase and immigration, have increased the demand for housing and many informal settlements have been built in these marginal areas [56-58]. A classic example of this dynamic was the colonization of the steep slopes to the northeast of Medellín (e.g., Santo Domingo) that began in the 1950s [59]. Today, these areas are some of the most densely urbanized in Medellín, with over 400 dwellings per hectare [30]. In contrast, the majority of expansion during the last 20 years has occurred in high income municipalities (e.g., Sabaneta, Envigado) in the southern part of the city (Figure 5(b)). This growth has included new industrial areas and gated communities [60]. In Bogotá, urban growth occurred largely on the southern edge of the city, specifically in the poor neighborhoods of Usme, Ciudad Bolívar, and Soacha (Figure 5(b)). These areas were classified as suburban (DN > 20-52) in 1992 and shifted to central core (DN > 60-63) by 2009 (Figures 4 and 5(a,b)). Currently these neighborhoods are the fastest growing and most densely populated areas in Bogotá [57,61]. Ciudad Bolívar concentrates the poorest population (estimated between 800,000 and 2 million inhabitants), most of them immigrants and displaced people [56,61]. In Bogotá, the lack of land has also led to urban development in wetland areas; approximately $80 \%$ of Bogotá's wetlands have been urbanized [57]. This tendency to occupy vulnerable and environmentally hazardous areas was also observed in Cali. Urban growth in Cali occurred largely to the east (Figure 5(b)), particularly in the southeast (e.g., Aguablanca). This area is the poorest and most densely populated neighborhood in Cali, dominated by informal settlements located in flood-prone areas on the marshy plains of the Río Cauca [62].

Similarly, virtually all urban development in Guayaquil has occurred in wetland ecosystems because the city is located in a low and marshy area ( $4.5 \mathrm{~m}$ above sea level) between the Guayas River and the Salado Estuary [55]. Consequently, many informal settlements have been established in flood-prone areas without proper planning [56]. Recent urban growth in Guayaquil occurred largely to the east of the city center, spreading into the hilly hinterlands of Eloy Alfaro and Durán on the left 
bank of the Guayas River (Figure 5(b)). In Quito, since the city center is limited by the Andes to the east and by the Pichincha Volcano to the west, most of the urban expansion occurred to the south and east (Figure 5(b)) into agricultural lands in the valleys of Chillos, Tumbaco, and Cumbaya. Most of the development in these areas was dominated by low-density and low-rise structures [57]. Consequently, Quito has the smallest central core and the lowest urban population density of the eight cities studied (Figures 4 and 5(b)), yet having one of the highest population growth rates (Table 1).

Landscape characteristics are also an important factor defining urbanization dynamics in Lima, which is located in a narrow desert coastal plain. The central core of Lima expanded mostly to the south, particularly in the municipality of Villa El Salvador (Figure 5(b)). In the early 1990's, the main land covers of this municipality were deserts and agricultural lands, but illegal land invasions have converted many areas into informal settlements [63]. For example, in January 2000, land zoned for agriculture and livestock grazing in this municipality was invaded by more than 10,000 squatters [64]. Presently, Villa El Salvador is one of Lima's largest low-income municipalities, with over 400,000 inhabitants and where $\sim 50 \%$ of the population lives below the poverty line [65]. Although there are no official statistics, estimates show that $20 \%-30 \%$ of the city's population live in informal settlements [63].

Urbanization dynamics in La Paz/El Alto in the Altiplano of Bolivia were also shaped by the geographic conditions of the area, specifically by the restrictions of land availability in the city center which is located in a steep and narrow valley. According to the analysis of NTL, the central core expanded west into the municipality of El Alto (Figure 5(b)), where the terrain is characterized by flat highlands with no physical barriers for urban expansion. Originally a neighborhood of La Paz, El Alto became an autonomous municipality in 1988 due to rapid urban growth caused by high immigration and the lack of space in La Paz city center [66]. The population of El Alto increased from 400,000 in 1992 to $\sim 1$ million in 2009, accounting for over 50\% of the total city population [29]. Currently, the majority of the manufacturing industries in the Bolivian highlands are located in El Alto [27]. However, it is also the poorest area, commonly known as the "indigenous city" since $95 \%$ of the population is indigenous, mostly Aymara (75\%) and Quechua Indians that migrated from rural areas [27]. In 2006, about $80 \%$ of the population in El Alto lived in low-income settlements, and $70 \%$ lived on less than US\$1 per day [66].

Rather the contrary occurs in the Bolivian eastern lowlands of Santa Cruz, where the vast flatlands around the city center have no natural barriers that limit urban expansion, besides the Piraí River to the west (Figure 1). The physical characteristics of the terrain and the large influx of immigrants attracted by the 1990s economic boom following the discovery of large natural gas reserves in the region fueled rapid and uncontrolled urbanization [28]. The results showed that between 1992 and 2009, the urban population in Santa Cruz doubled, having the highest annual population growth rate of all the cities studied (Table 1). The analysis of NTL revealed that the central core of Santa Cruz expanded, but the most important dynamic was the wide expansion of compact and suburban urban areas to the east and south of the city center (Figures 4 and 5(b)). Most of these growing areas are located outside the city's concentric ring roads built to restrain urban growth as part of the Plan Techint urbanization scheme of 1960 [67]. Consequently, the original radial structure of the city has been altered by unplanned urban development outside the city's rings, mostly because the municipal authorities left urban development to private developers, subject mostly to market forces [28]. The absence of geographical barriers plus 
the expansive and uncontrolled urban growth are probably responsible for Santa Cruz's low population density levels (Table 1).

\subsubsection{Land Value and Housing Prices}

Landscape characteristics are also related to land value, a major driver of urban development [14]. Virtually all urban expansion in La Paz/El Alto occurred within the municipality of El Alto due to the availability of relatively inexpensive land. For example, the cost of renting in La Paz is approximately twice as expensive as in El Alto [68]. This has attracted middle-class households looking for affordable housing [27]. In the case of Santa Cruz, the high prices of rental properties, the lack of affordable housing in the city center, and the absence of policies to control land use and land speculation has encouraged illegal land dealers to sell state-owned land to rural migrants around the city periphery [28]. In the case of Cali in Colombia, the agricultural industry is one of the main economic activities for the city (e.g., sugar cane, coffee), and the high values of agricultural lands act as barriers for urban expansion [69]. Agricultural lands visibly mark the urban-rural frontier, particularly to the east. A similar dynamic is observed in Bogotá, where agricultural lands to the west of the city are mainly used for flower production. Flower exports are an important economic activity that generate over US $\$ 900 \mathrm{M}$ annually, thus limiting urban expansion [70]. Furthermore, the construction sector in Bogotá has experienced a deep financial crisis since the mid-1990s that has affected the provision of formal housing throughout the city, particularly for low-income families. Approximately 11,000 affordable housing units (US \$9,000-US \$11,000) are constructed annually in Bogotá; however the annual demand is $\sim 40,000$, forcing many families to settle in informal developments along the periphery of the city [28]. As a result, peripheral zones in Bogotá tend to have very high population densities, mostly due to overcrowding [71]. Accordingly, while urban sprawl has been the dominant growth pattern in most developing cities worldwide, the city of Bogotá has experienced a densification process during the last decades [72]. A recent study showed that the overall density in Bogotá increased $\sim 8 \%$ between 2001 and 2008, which represents an increase of approximately 1,400 inhabitants per square kilometer [71]. This dynamic is related to the densification of suburbs and peripheral zones, but also to the densification of areas served by the Transmilenio mass-transit bus system [71,72].

\subsection{Urban Density Levels in the Andean Region, a Global Perspective}

At the global scale, population densities in the Andean cities are representative of urban densities worldwide (Figure 6). Medellín, Bogotá, and Cali are at the high end of the density range and among the densest cities in the world alongside Kolkata and Hong Kong. Guayaquil, Lima and La Paz/El Alto have densities comparable to Mexico City and Delhi - two of the five most populated cities of the world [9]. Quito and Santa Cruz have densities typically found in other Latin American cities including Sao Paulo, Salvador, Rio de Janeiro, Havana, and Santiago (Figure 6), and comparable to Jakarta, the most populated city in Southeastern Asia. In some cases, these similarities in urban population densities among cities are associated with similar spatial patterns of urban development. For example, urban growth in Quito, Santa Cruz, and Jakarta is characterized by the conversion of agricultural lands to low-density suburban development [73]. The variance between the UN estimates 
and our estimates of urban population density in Andean cities (Figure 6), is related with differences in the land area considered, since population size in both estimates was similar. For Santa Cruz, La Paz/El Alto and Lima, the land area reported by the UN was smaller than our estimate of urban land area; the opposite for Quito.

Figure 6. Comparison of our estimates of urban population density in Andean cities with the densities of other Latin American cities and major cities around the world, according to the United Nations estimates for urban agglomerations [19].

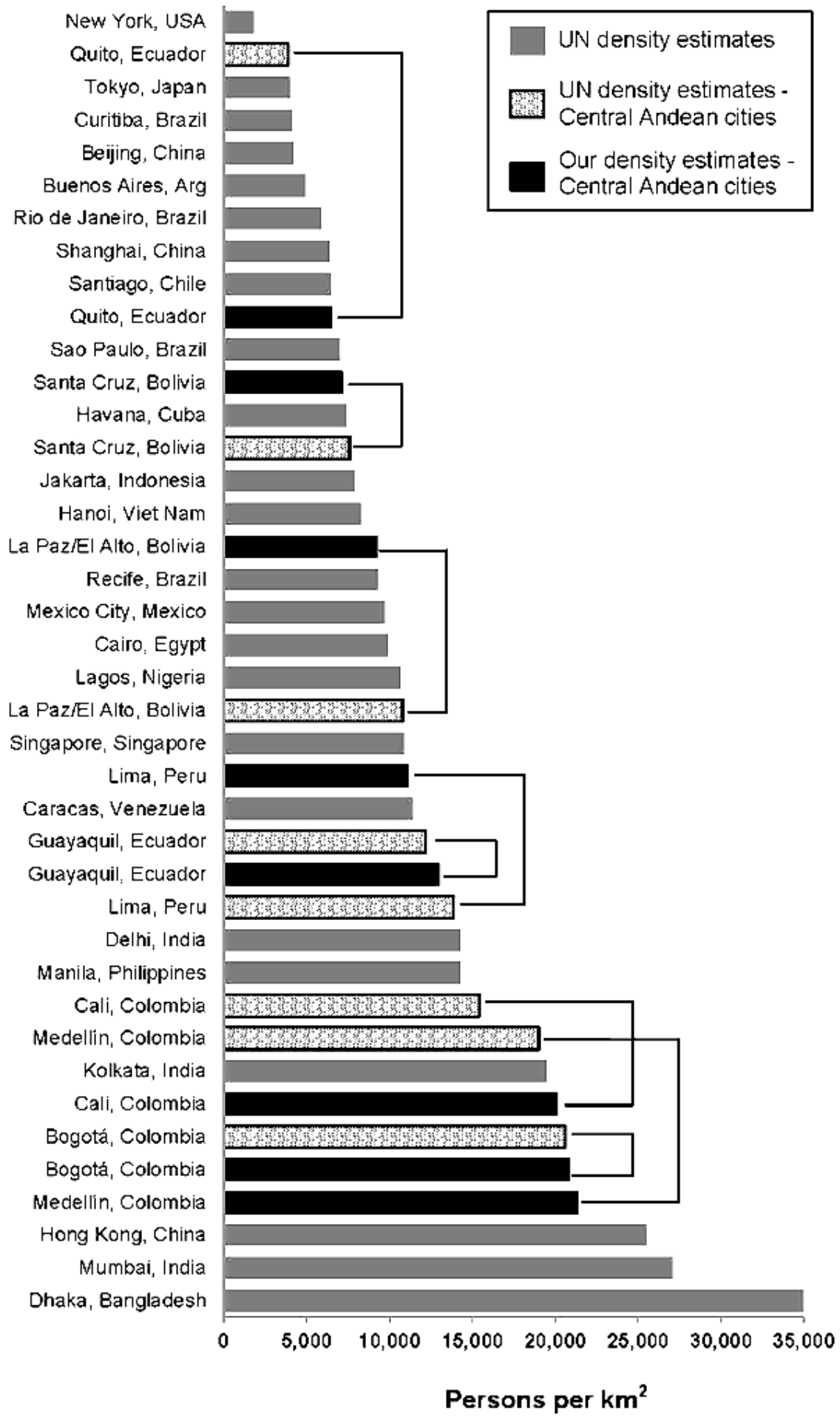




\section{Conclusions}

Some studies suggest that urban population densities in Latin American will decline as cities become more affluent and more decentralized [74]. Furthermore, poorer countries are expected to have cities with higher population densities [75] and lower levels of per capita land consumption [40]. Our analyses showed the opposite. The most densely populated cities were in Colombia, which had the highest country-level GDP, while La Paz/El Alto, Santa Cruz, and Quito had lower GDP and low population densities (Table 1). In addition, urban development in the Colombian cities was characterized by densification and low land consumption, while urban development in Santa Cruz and Quito was more expansive (Figure 5(a,b)). Presumably, the future scenario of urban growth in cities of the Andean region will be densification and deceleration in the rate of urban expansion, which probably will be accompanied by informality, poverty, and marginalization [8,13]. It has been estimated than $70 \%$ of the urban growth in low and middle income countries occurs outside the formal planning process [12].

Many of the environmental problems in cities are precisely a consequence of poor planning and deficient public administration, underlined by the lack of well-defined policies rather than from urbanization itself [9]. For example in Bolivia, the conurbation formed by the municipalities of La Paz and El Alto is considered one of the fastest growing cities in the world; however, the municipalities are administrated separately and unequally [27]. This fragmented governance structure hinders adequate planning and city management, negatively affecting the provision of goods and services (e.g., housing, transport, sanitation, employment), and enhancing social and economic disparity. The same occurs in Lima, where the continuous urban built-up area includes 38 municipalities (Table 1) that are politically autonomous and administrated separately [63].

Globally, the extent of urban areas is expanding rapidly, but do we have the governance and planning structures or tools necessary to effectively manage these cities? At the most basic level, governance and planning activities must adapt to larger areas as cities grow and merge with adjacent towns forming metropolitan areas. To be effective, it is essential that city planners and decision-makers have access to up-to-date accurate spatial data at the city and metropolitan scale. The present study shows how free, and current spatial information (e.g., Google Earth, NTL data) can be combined to provide urban planners with invaluable information for tracking urban development patterns. In addition to accurate urban spatial data, it is essential to integrate governance and citizen participation in developing solutions for the diverse challenges (e.g., water availability, energy and food security, adaptation to climate change) of these growing metropolitan areas [76].

\section{Acknowledgments}

This project was funded by a grant from the Coupled Natural and Human Systems program of the U.S. National Science Foundation (\# 0709598). The NSF Integrative Graduate Education and Research Traineeship Program (\#0801577) and the NSF Graduate Research Fellowship Program provided financial support to N.A-B. We also thank Andrés Etter, Miguel Acevedo, and four anonymous reviewers for their help and useful comments. 


\section{References}

1. OECD Environmental Outlook to 2050: The Consequences of Inaction; Organization for Economic Co-operation and Development: Paris, France, 2012; p. 350.

2. World Urbanization Prospects: The 2011 Revision; Population Division, Department of Economic and Social Affairs, United Nations: New York, NY, USA, 2012; p. 302.

3. Ziólkowski, J.A. Trends in Sociological Research in Urbanization in Europe. Presented at the Seminar on Urban Development Policy and Planning, Warsaw, Poland, August 1962; p. 12.

4. Angel, S.; Parent, J.; Civco, D.L.; Blei, A.M. Making Room for a Planet of Cities; Lincoln Institute of Land Policy: Cambridge, MA, USA, 2011; p. 76.

5. Cadena, A.; Remes, J.; Manyika, J.; Dobbs, R.; Roxburgh, C.; Elstrodt, H.P.; Chaia, A.; Restrepo, A. Building Globally Competitive Cities: The Key to Latin American Growth; McKinsey Global Institute: San Francisco, CA, USA, 2011; p. 15.

6. Seto, K.C.; Fragkias, M.; Güneralp, B.; Reilly, M.K. A meta-analysis of global urban land expansion. PloS one 2011, 6, e23777.

7. Schneider, A.; Woodcock, C.E. Compact, dispersed, fragmented, extensive? A comparison of urban growth in twenty-five global cities using remotely sensed data, pattern metrics and census information. Urban Stud. 2008, 45, 659-692.

8. Bolay, J.C. What sustainable development for the cities of the South? Urban issues for a third millennium. Int. J. Urban Sustain. Dev. 2012, 4, 76-93.

9. State of the World's Cities 2008/2009-Harmonious Cities; UN-Habitat: Nairobi, Kenya, 2008; p. 204.

10. Geng, Y.; Peng, C.; Tian, M. Energy use and $\mathrm{CO}_{2}$ emission inventories in the four municipalities of China. Energy Procedia 2011, 5, 370-376.

11. UNW-DPAC. Water and Cities Facts and Figures. In Proceedings of Sustainable Water Management in Cities: Engaging Stakeholders for Effective Change and Action, Zaragoza, Spain, 13-17 December 2010; p. 4.

12. Potsiou, C.; Doytsher, P.; Khouri, R.; McLaren, R.; Mueller, H. Rapid Urbanization and Mega Cities: The Need for Spatial Information Management. Presented at the XXIV FIG International Congress, Sydney, Australia, 11-16 April 2010; p. 25.

13. Davis, M. Planet of slums. Common Knowl. 2008, 14, 5-34.

14. Fernandes, E. Regularization of Informal Settlements in Latin America; Lincoln Institute of Land Policy: Cambridge, MA, USA, 2011; p. 52.

15. Giralt, E., Andrew, D., Eds. World Development Report 2011; The World Bank Group: Washington, DC, USA, 2011; Volume 2011, p. 416.

16. The Challenge of Slums: Global Report on Human Settlements 2003; UN-Habitat: Nairobi, Kenya, 2012; p. 344.

17. Inostroza-Pino, L.; Baur, R.; Csaplovics, E.; Willet, B. Urban Sprawl and Fragmentation in Latin America: A Comparison with European Cities - The Myth of the Diffuse Latin American City; Lincoln Institute of Land Policy: Cambridge, MA, USA, 2010.

18. Cohen, B. Urbanization in developing countries: Current trends, future projections, and key challenges for sustainability. Cities 2006, 28, 63-80. 
19. World Urbanization Prospects: The 2009 Revision-Highlights; Population Division, Department of Economic and Social Affairs, United Nations: New York, NY, USA, 2010; Volume 24, p. 47.

20. Alvarez-Berríos, N.L.; Parés-Ramos, I.K.; Aide, T.M. Contrasting patterns of urban expansion in Colombia, Ecuador, Peru, and Bolivia Between 1992 and 2009. Ambio 2012, 42, 29-40.

21. Skinner, R. City profile: Bogotá. Cities 2004, 21, 73-81.

22. Ortiz, A. Cali, Colombia: Toward a City Development Strategy; The World Bank Group: Washington, DC, USA; 2002; p. 112.

23. Brand, P. Ecologism and urban space: Nature, urbanisation and city planning in Medellin, Colombia. Plann. Pract. Res. 1995, 10, 55-66.

24. Quito Environment and Climate Change Outlook (ECCO-Q); United Nations Environment Programme: Nairobi, Kenya, 2011; p. 192.

25. Delgado, A. Guayaquil. J. Cities 2011, doi:10.1016/j.cities.2011.11.001.

26. Leonard, J. City profile: Lima. Cities 2000, 17, 433-445.

27. Arbona, J.M.; Kohl, B. City profile: La Paz-El Alto. Cities 2004, 21, 255-265.

28. Kirshner, J.D. City profile: Santa Cruz de la Sierra. Cities 2012, doi:10.1016/j.cities.2011.12.009.

29. Census of Population, Housing and Socio-Demographic Indicators; Instituto Nacional de Estadística (INE): Bolivia, 2011.

30. Census of Population; Departamento Administrativo Nacional de Estadística (DANE), Colombia, 2011.

31. Census of Population and Housing; Instituto Nacional de Estadística y Censos (INEC), Ecuador, 2011.

32. Census of Population and Housing; Instituto Nacional de Estadística e Informática (INEI), Perú, 2011.

33. Clark, M.L.; Aide, T.M. Virtual Interpretation of Earth Web-Interface Tool (VIEW-IT) for collecting land-use/land-cover reference data. Remote Sens. 2011, 3, 601-620.

34. Fritz, S.; See, L.; McCallum, I.; Schill, C.; Perger, C.; Obersteiner, M. Building a CrowdSourcing Tool for the Validation of Urban Extent and Gridded Population. In Computational Science and Its Applications ICCSA 2011; Murgante, B., Gervasi, O., Iglesias, A., Taniar, D., Apduhan, B., Eds.; Springer: Berlin/Heidelberg, German, 2011; Volume 6783, pp. 39-50.

35. Dorais, A.; Cardille, J. Strategies for incorporating high-resolution google earth databases to guide and validate classifications: Understanding deforestation in Borneo. Remote Sens. 2011, 3, 1157-1176.

36. Doll, C.N.H. CIESIN Thematic Guide to Night-Time Light Remote Sensing and its Applications. Center for International Earth Science Information Network (CIESIN), Columbia University: Palisades, NY, USA, 2008; pp. 1-41.

37. Welch, R. Monitoring urban population and energy utilization patterns from satellite data. Remote Sens. Environ. 1980, 9, 1-9.

38. Amaral, S.; Camara, G.; Monteiro, A.; Quintanilha, J.; Elvidge, C. Estimating population and energy consumption in Brazilian Amazonia using DMSP night-time satellite data. Comput. Environ. Urban Syst. 2005, 29, 179-195.

39. Sutton, P.; Roberts, D.; Elvidge, C.; Melj, H. A comparison of nighttime satellite imagery and population density for the continental United States. Society 1997, 63, 1303-1313. 
40. Sutton, P.; Roberts, D.; Elvidge, C.; Baugh, K. Census from heaven: An estimate of the global human population using night-time satellite imagery. Int. J. Remote Sens. 2001, 22, 3061-3076.

41. Zhang, Q.; Seto, K.C. Mapping urbanization dynamics at regional and global scales using multi-temporal DMSP/OLS nighttime light data. Remote Sens. Environ. 2011, 115, 2320-2329.

42. Lo, C.P. Urban indicators of China from radiance-calibrated digital DMSP-OLS nighttime images. Ann. Assoc. Am. Geogr. 2002, 92, 225-240.

43. Elvidge, C.D.; Baugh, K.E.; Kihn, E.A.; Kroehl, H.W.; Davis, E.R.; Davis, C.W. Relation between satellite observed visible-near infrared emissions, population, economic activity and electric power consumption. Int. J. Remote Sens. 1997, 18, 1373-1379.

44. Ghosh, T.; Sutton, P.; Powell, R.; Anderson, S.; Elvidge, C.D. Estimation of Mexico's Informal Economy Using DMSP Nighttime Lights Data. In Proceedings of the Joint Urban Remote Sensing Event 2009, Shanghai, China, 20-22 May 2009; pp. 1-10.

45. Sutton, P.C.; Costanza, R. Global estimates of market and non-market values derived from nighttime satellite imagery, land cover, and ecosystem service valuation. Ecol. Econ. 2002, 41, 509-527.

46. Muller, J.; Elvidge, C.D. Night-time imagery as a tool for global mapping of socioeconomic parameters and greenhouse gas emissions. Ambio 2000, 29, 157-162.

47. Liu, Q.; Sutton, P.C.; Elvidge, C.D. Relationships between Nighttime Imagery and Population Density for Hong Kong. In Proceedings of the 31st Asia-Pacific Advanced Network Meetings, Hong Kong, China, 21-25 January 2011; Volume 31, pp. 80-91.

48. Sutton, P. Modeling population density with night-time satellite imagery and GIS. Comput. Environ. Urban Syst. 1997, 21, 227-244.

49. Elvidge, C.D.; Baugh, K.E.; Anderson, S.J.; Sutton, P.C.; Ghosh, T. The Night Light Development Index (NLDI): A spatially explicit measure of human development from satellite data. Soc. Geogr. 2012, 7, 23-35.

50. Liu, Z.; He, C.; Yang, Y. Mapping Urban Areas by Performing Systematic Correction for DMSP/OLS Nighttime Lights Time Series in China from 1992 to 2008. In Proceedings of 2011 IEEE International Conference on GeoScience and Remote Sensing Symposium (IGARSS), Vancouver, BC, Canada, 24-29 July2011; pp. 1858-1861.

51. Ma, T.; Zhou, C.; Pei, T.; Haynie, S.; Fan, J. Quantitative estimation of urbanization dynamics using time series of DMSP/OLS nighttime light data: A comparative case study from China's cities. Remote Sens. Environ. 2012, 124, 99-107.

52. Sutton, P.; Goetz, A.; Fildes, S.; Forster, C.; Ghosh, T. Darkness on the edge of town: Mapping urban and peri-urban Australia using nighttime satellite imagery. Prof. Geogr. 2010, 62, 119-133.

53. United Nations; CEPALSTATS. Indicadores Sociales Vivienda Hogares con disponibilidad de servicios básicos en la vivienda, por área urbana y rural. Available online: http://websie.eclac.cl (accessed on 1 July 2012).

54. Galster, G.; Hanson, R.; Ratcliffe, M.R.; Wolman, H.; Coleman, S.; Freihage, J. Wrestling sprawl to the ground: Defining and measuring an elusive concept. Housing Policy Debate 2001, 12, 681-717. 
55. Herold, M.; Roberts, D.A. The Spectral Dimension in Urban Remote Sensing. In Remote Sensing of Urban and Suburban Areas; Juergens, C., Rashed, T., Eds.; Springer: London, UK, 2008; p. 300.

56. Rojas, N. The art of development images promoting dialogue and alternatives to poverty and violence in local communities of Colombia. Consilience 2011, 5, 190-200.

57. Salazar Ferro, J. Bogotá's Recovery Process. In Megacities Urban Form, Governance, and Sustainability; Sorensen, A., Okata, J., Eds.; Springer: New York, NY, USA, 2010; p. 262.

58. Rueda-García, N. Urban Slums Reports: The Case of Bogotá, Colombia. In Understanding Slums: Case Studies for the Global Report; United Nations Human Settlements Programme: Nairobi, Kenya; Development Planning Unit, University College London: London, UK, 2003; p. 32.

59. Ballesteros, J.E.; Velásquez, C.; Sierra, M.; Torre, E.; Vélez, E. Santo Domingo Savio: un territorio reterritorializado (in Spanish). Territorios 2010, 22, 87-110.

60. Gaviria-Gutiérrez, Z. La expansión urbana sobre las periferias rurales del entorno inmediato a la ciudad metropolitan (in Spanish). Revista Soluciones de Postgrado EIA 2009, 3, 63-74.

61. Vargas, C.S.J. Displaced people in Bogotá and Soacha: Characteristics and protection. Revista de Paz y Conflictos 2011, 4, 102-120.

62. Davila, J. Urban Poverty Reduction Experiences in Cali, Colombia: Lessons from the Work of Non-profit Organisations; Human Settlements Working Paper Series Poverty Reduction in Urban Areas No. 4; International Institute for Environment and Development: London, UK, 2002.

63. Riofrío, G. Urban Slums Reports: The Case of Lima, Peru. In Understanding Slums: Case Studies for the Global Report; United Nations Human Settlements Programme: Nairobi, Kenya; Development Planning Unit, University College London: London, UK, 2003; p. 15.

64. Imparato, I.; Ruster, J. Slum Upgrading and Participation: Lessons from Latin America; The World Bank Group: Washington, DC, USA, 2003; p. 489.

65. Bontenbal, M.; Van Lindert, P. Bridging local institutions and civil society in Latin America: can city-to-city cooperation make a difference? Environ. Urban. 2008, 20, 465-481.

66. Iriarte, G. Análisis crítico de la realidad, 17th ed.; Editorial Quipus: Cochabamba, Bolivia, 2007; p. 698.

67. Prado Salmón, F. Perfil ambiental de Santa Cruz de la Sierra; Institute for Housing and Urban Development Studies (HIS), Erasmus University: Rotterdam, The Netherlands, 2000; p. 49.

68. Hernani-Limarino, W.L.; Jimenez, W.; Arias, B.; Larrea, C. Research Proposal: The Quality of Life of Urban Neighborhoods in Bolivia: A Case of Study of the Great La Paz and Santa Cruz. Available online: www.iadb.org/res/laresnetwork/files/pr302finaldraft.pdf (accessed on 2 November 2012).

69. Dureau, F.; Barbary, O.; Gouëset, V.; Pissoa, O.; Dureau, T. Ciudades y sociedades en mutación Lecturas cruzadas sobre Colombia, 1st ed.; Bogotá Universidad Externado de Colombia: Bogotá, Colombia, 2007; Volume 1, p. 470.

70. Madrid, G.; Lovell, T. Working with flowers in Colombia: the "lucky chance"? Work 2007, 30, 217-227.

71. Bocarejo, J.P.; Portilla, I.; Pérez, M.A. Impact of Transmilenio on density, land use, and land value in Bogotá. Res. Transport. Econ. 2013, 40, 78-86. 
72. Wessels, G.; Pardo, C.F.; Bocarejo, J.P. Report. Bogota 21: Toward a World-Class Transit-Oriented Metropolis; Bogotá, Colombia, 2012; p. 105.

73. Rustiadi, E.; Panuju, D.R. Spatial Pattern of Suburbanization and Land-Use Change Process: Case Study in Jakarta Suburb. In Land-Use Changes in Comparative Perspective; Himiyama, Y., Hwang, M., Ichinose, T., Eds.; Enfield Publishing \& Distribution Co.: Enfield, NH, USA; p. 262.

74. Gilbert, A. Employment and poverty during economic restructuring: The case of Bogotá, Colombia. Urban Studies 1997, 34, 1047-1070.

75. Sutton, P. A scale-adjusted measure of "urban sprawl" using nighttime satellite imagery. Remote Sens. Environ. 2003, 86, 353-369.

76. Kearns, A.; Paddison, R. New challenges for urban governance. Urban Studies 2000, 37, 845-850.

(C) 2013 by the authors; licensee MDPI, Basel, Switzerland. This article is an open access article distributed under the terms and conditions of the Creative Commons Attribution license (http://creativecommons.org/licenses/by/3.0/). 